ISSN 2338-5324 (print)

ISSN 2442-7276 (online)

Online di http://jkp.fkep.unpad.ac.id

DOI : $10.24198 / \mathrm{jkp}$

\title{
Relationship between Academic Stress, Family and Peer Attachment with Internet Addiction in Adolescents
}

\author{
Gusti Agung Ayu Putu Putri Ariani' ${ }^{1}$, Suryani ${ }^{2}$, Taty Hernawaty ${ }^{2}$ \\ ${ }^{1}$ Health Polytechnic Gorontalo, ${ }^{2}$ Faculty of Nursing, Universitas Padjadjaran \\ Email: putriariani666@gmail.com
}

Submitted: 17-08-2017 Accepted: 25-12-2018 Published: 25-12-2018

\begin{abstract}
Biological, psychological and social changes make adolescents at risk of various health problems in the community. The ease of internet access nowadays makes adolescent more vulnerable to internet addiction. In Indonesia, many studies examine the relationship between internal factors such as low self-esteem, loneliness and the type of personality with internet addiction. Further research is still needed that focuses on external factors such as academic stress, family and peer attachment. This study aimed to examine the relationship of academic stress, family and peer attachment with internet addiction in high school adolescents in Andir District, Bandung City. The study used a quantitative correlational design with a cross-sectional approach. The population was high school adolescents. A total sample of 367 adolescents was determined using the slovin formula with alpha Cronbach 0.05 . Respondents were recruited using random cluster sampling. Data were analyzed using Rank Spearman and Logistic Regression. Statistical tests of academic stress variables showed, family and peer attachments were significantly related with internet addiction in adolescents $(p=0.000)$; family attachment variable was significantly related to internet addiction in adolescents $(\mathrm{p}=0.000)$, and peer attachment was significantly related with internet addiction in adolescents $(\mathrm{p}=0.000)$. Logistic regression tests showed the family attachment variable had a significant influence on internet addiction in high school adolescents. In conclusion, there are correlations between academic stress, family and peer attachment to internet addiction. The family attachment has the most significant influence with internet addiction in high school adolescents. It is essential for community mental health nurses to conduct health education to families related to the result of this study.
\end{abstract}

Keywords: Academic stress, adolescent, family attachment, internet addiction, peer attachment. 
Putri Ariani : Relationship Between Academic Stress, Family And Peer Attachment

\section{Introduction}

Adolescents are a group that occupies a sizeable population reaching around $18 \%$ or 1.2 billion of the world's population (WHO, 2015). In adolescence, the young will experience periods of growth and development, where individuals experience changes from childhood to adulthood followed by biological, psychological and social changes (Santrock, 2005). These three aspects put adolescents at risk of various health problems in the community.

Risk behaviors that often occur in adolescents include alcohol use, suicide, depression, academic stress, premarital sexual behavior and internet addiction (Stanhope \& Lancester, 2004; Wang et al., 2011). Internet addiction in adolescents is characterized by the difficulty of controlling the desire to continue using the Internet so that if stopped, it will cause feelings of depression (Yang \& Tung, 2014).

The survey conducted by the Indonesian Internet Network Organizing Association (APJII) throughout 2016 found that 51.8\% of Indonesia's population used the internet, and $75 \%$ of internet users were dominated by teenagers aged 10-24 years. Bandung is the third city with the highest internet users reaching $17.22 \%$, after Jakarta with prevalence reaching $33.3 \%$ and Surabaya $22.4 \%$.

The high use of the internet among teenagers can increase the occurrence of internet addiction. The results of the literature search show that internet addiction in adolescents can be influenced by two factors, namely internal factors, and external factors. Internal factors include loneliness (Karimpoor et al., 2013; Saleem, Khan, \& Ismail, 2015), low self-esteem (Aydn \& Sar, 2011), and neuroticism personality (Ozturk et al., 2015; Dieres \& Hirche, 2017). External factors include adolescents who have families that have problems in family function (Tsitsika et al., 2013; Park et al., 2013), study load and peer influence (Wang et al., 2011; Gunuc \& Dogan, 2013).

The study of Yen, Chen, and Ko (2007) in Taiwan found family factors such as parental marital status, family economic status, family conflict, and parenting significantly related to drug use and internet addiction. The results of the study are in line with the research of Wu et al. (2016) in China, which found that teenagers who are addicted to the internet come from families who often experienced conflict and divorce. This finding is reinforced by the study of Park, Kim, and Cho (2008), who found that family attitudes, lack of communication in the family, violent behavior in adolescents have a high risk of internet addiction.

In addition to the family factors above, a study by Pattayakorn (2012) toward 341 students in Thailand found that students who have a high study load, the numerous assignments can increase stress resulting in students experiencing internet addiction. This condition is in line with the study of Kandemir (2014) in Turkey, who found that students' academic procrastination behavior is significantly related to stress and internet addiction.

Jun and Choi's study (2015) found that adolescents who experience academic pressure and negative emotions are associated with internet addiction while the study of Akhter (2013) found that academic stress is not significantly associated with internet addiction in teenagers in Pakistan. According to Wang, Zhou, and $\mathrm{Lu}$ (2011), the risk factors for adolescents experiencing internet addiction are related to stress, bad relationships with teachers and friends and experiencing conflict within the family. This is in line with Bakken et al. (2009), who stated that groups of adolescents aged 14 to 19 who experience internet addiction because they avoid stress or responsibility.

Several studies have been performed related to internet usage associated with stress in adolescents in Indonesia. Permatasari (2016) conducted a study on the relationship of stress with the tendency of internet addiction in adolescents aged 13-18 years in Surabaya found there is a significant relationship between stress levels and the trend of internet addiction in adolescents. This is in line with the research of Piyike, Bidjuni, and Wowiling (2014) toward 88 adolescents in Manado City who found a significant relationship between stress levels in adolescents with online game addiction. Another study by Karuniawan and Cahyanti (2013) toward 
Putri Ariani : Relationship Between Academic Stress, Family And Peer Attachment

221 adolescents, found academic stress in adolescents has a significant relationship with smartphone addiction. Besides family factors and academic stress, a study by Soh, Charlton, and Chew (2014) found that peer influence has a significant relationship with internet addiction. This result is supported by the study of Gunuc (2016) who found that peer influence is significantly related to online game addiction in adolescents.

A preliminary study conducted on 20 high school students in Andir Subdistrict, Bandung City, found that two students used the internet since elementary school, 12 students used the internet since junior high school, and four people used the internet since high school. Eight students reported that they used the internet for more than 6 hours per day and 12 students used the internet for less than 6 hours per day. All students interviewed confirmed that they often visited the Google site for school assignments, YouTube and online games for entertainment, then social media such as Instagram, Facebook, line, vlog.

Search results for literature abroad and in Indonesia discovered many studies were conducted on the relationship between internal factors such as low self-esteem, loneliness, personality, and internet addiction. In Indonesia alone, studies related to external factors are still few. To strengthen the study results related to external factors connected to internet addiction, researchers felt the need to conduct a study on "The relationship between academic stress, family and peer attachment with internet addiction in high school adolescents in Andir District, Bandung."

\section{Method}

This study used a cross-sectional design. The sample in this study amounted to 367 teenagers from 14 high schools. The sampling technique used the random cluster sampling by writing all numbers based on the respondent's attendance number on paper rolls; then by using a glass, it was shaken so that each respondent had the same opportunity and was dropped according to the amount needed. Next, the researcher coordinated with the school to collect data by collecting selected respondents in a room.
The instruments used included the Internet Addiction Test (IAT) to measure the potential of internet addiction, Educational Stress Scale for Adolescents (ESSA) was used to measure academic stress, and Inventory Parents and Peers (IPPA) which was developed by Greenberg and Armsden (2009) to measure the attachment of father and mother as well as peers in adolescents.

The data analysis consisted of univariate, bivariate and multivariate. The bivariate analysis used the Rank Spearman test and Multivariate analysis used logistic regression.

This research received the ethical approval from the Health Research Ethics Commission of the Faculty of Medicine, Universitas Padjadjaran with number 77/UN6.c.10/ $\mathrm{PN} / 2017$.

\section{Result}

This research was conducted for three weeks in 14 high schools in the Andir District of Bandung City. The time of the study began from May 30 to June 16, 2017. The study subjects were high school students in grades 10 and 11.

Based on Table 1, most high school adolescents lived with parents, namely 307 adolescents or $83.4 \%$. Besides that, teens used the internet more to access social media with $56.1 \%$, followed by using the internet to play online games by $17.7 \%$. Most of the teens used the internet $<6$ hours/day, amounting to 210 teenagers or $57.2 \%$ and the rest as much as 157 teenagers used the internet $>6$ hours/ day.

Table 2 showed the frequency distribution of academic stress, family attachments and peers. In the academic variable, adolescents experienced more academic stress in the moderate category, amounting to $130(35.4 \%)$. However, this number was not much different from adolescents who experienced academic stress in the high category consisting of 121 adolescents or $31.6 \%$ and low categories 116 or $33.0 \%$.

In the family and peer attachments more than half of the adolescents had family and peer attachments in the medium category, each of which amounted to $221(60.2 \%)$ in family attachment and $201(54.7 \%)$ in peer 
Putri Ariani : Relationship Between Academic Stress, Family And Peer Attachment

Table 1 Frequency Distribution of Sociodemographic of High School Adolescents in Andir District, Bandung City $(\mathrm{n}=367)$

\begin{tabular}{lcc}
\hline \multicolumn{1}{c}{ Sociodemography } & Frequency & Percentage (\%) \\
\hline Live together with & 307 & 83.4 \\
both biological parents & 38 & 10.3 \\
One of the biological parents & 22 & \\
(father/mother) & & 6.0 \\
Guardian & & \\
Primary Purpose of Using the & 206 & 56.1 \\
Internet & 65 & 17.7 \\
Social Media & 47 & 12.8 \\
Online Game & 40 & 10.9 \\
Searching for Information & 8 & 2.2 \\
Communication & 1 & 0.3 \\
Online Shopping & & \\
Pornography & 210 & 57.2 \\
Duration of Internet usage in a day & 157 & 42.8 \\
$\leq 6$ hours /day & & \\
$>\quad 6$ hours /day & & \\
\hline
\end{tabular}

Table 2 Frequency Distribution of Academic Stress, Family Attachment, and Peers with Internet Addiction $(\mathrm{n}=367)$

\begin{tabular}{lcc}
\hline \multicolumn{1}{c}{ Sociodemography } & Frequency & Percentage (\%) \\
\hline Live together with & 307 & 83.4 \\
both biological parents & 38 & 10.3 \\
$\begin{array}{l}\text { One of the biological parents } \\
\text { (father/mother) }\end{array}$ & 22 & 6.0 \\
Guardian & & \\
Primary Purpose of Using the & 206 & 56.1 \\
Internet & 65 & 17.7 \\
Social Media & 47 & 12.8 \\
Online Game & 40 & 10.9 \\
Searching for Information & 8 & 2.2 \\
Communication & 1 & 0.3 \\
Online Shopping & & \\
Pornography & 210 & 57.2 \\
Duration of Internet usage in a day & 157 & 42.8 \\
$\leq 6$ hours /day & & \\
$>\quad 6$ hours /day & & \\
\hline
\end{tabular}

attachment. In contrast, the lowest percentage was in the high attachment category with a rate of $6.2 \%$ in family attachment and $14.7 \%$ in peer attachment.

Based on internet addiction, half of the total respondents experienced moderate dependence with a total of 201 (54.8\%). Meanwhile, adolescents included in the category of internet addiction amounted to 37 $(10.1 \%)$, and only a few teenagers used the 
Putri Ariani : Relationship Between Academic Stress, Family And Peer Attachment

Table 3 Correlation between Academic Stress, Family Attachments, and Peers with Internet Addiction in High School Adolescents

\begin{tabular}{lcc}
\hline & Internet Addiction $(\mathbf{n}=\mathbf{3 6 7})$ & \\
\hline & $\mathbf{r}$ & $\mathbf{p}$-value \\
\hline Academic stress & 0.525 & 0.000 \\
Family attachment & 0.398 & 0.000 \\
Peer attachment & 0.360 & 0.000 \\
\hline
\end{tabular}

Note: Coefficient correlation Rank Spearman

Table 4 Multivariate Analysis of Academic Stress, Family and Peer Attachment

\begin{tabular}{lccccc}
\hline & $\begin{array}{c}\text { Internet Addiction } \\
(\mathbf{n = 3 6 7 )}\end{array}$ & & & & \\
\hline Variable & $\mathbf{B}$ & SE & Wald & OR & p-value \\
\hline Family attachment & -1.213 & 0.297 & 16.665 & 0.297 & 0.532 \\
Peer attachment & -1.461 & 0.317 & 21.197 & 0.232 & 0.432 \\
Academic stress & -3.729 & 0.749 & 24.796 & 0.024 & 0.104 \\
\hline
\end{tabular}

Note: *significant at $\alpha=0,05$

internet in the normal category, amounting to 13 people or $3.5 \%$.

Table 3 showed, the statistical test results found a relationship between academic stress and internet addiction in high school adolescents ( $p$-value $=0.000$ ). The relationship of academic stress with internet addiction showed a strong bond and had a positive relationship direction which meant that the higher the academic stress, the higher the teenager was at risk of experiencing internet addiction.

Furthermore, the results of statistical tests obtained were that there was a relationship between family attachment and internet addiction in high school adolescents ( $\mathrm{p}$-value $=0.000$ ). The relationship between family attachment and internet addiction showed a weak correlation and had a positive direction, which means that the lower the family attachment, the higher the risk of teenagers becoming addicted to the internet. Moreover, the statistical tests showed that there was a relationship between peer attachment and internet addiction in high school adolescents $(p$-value $=0.000)$. The relationship of peer attachment with internet addiction shows a weak link and has a negative relationship direction which means that the higher the peer attachment, the lower the risk of teenagers experiencing internet addiction.

In the logistic regression analysis, the order of the strength of the correlation or the relationship of the variables that influenced the dependent variable is known from the value of the $\operatorname{Exp}(\mathrm{B})$ or Odds Ratio (OR). The results of the multivariate analysis in this study found that the strength of the relationship from the smallest to the largest was academic stress $(\mathrm{OR}=0.024)$, peer attachment $(\mathrm{OR}=$ $0.232)$, and family attachment $(\mathrm{OR}=0.297)$. Based on the OR value of the three variables, the family attachment variable was the most associated variable with internet addiction in adolescents.

\section{Discussion}

The characteristics of respondents, internet addiction can occur at any age, and in any socio-economic conditions, however, the main focus of the study was more on adolescence (Kuss, Rooij, Shorter, Griffiths, \& Van de Mheen, 2013).

Table 1 showed that $206 \quad(56.1 \%)$ respondents used the internet with the primary purpose of accessing social media. Social media is generally used to interact and socialize and establish friendships online (Lenhart et al., 2001). The increasing use of social media among teenagers was caused by various exciting features provided by social media, including teenagers can share information, express themselves by sending pictures that aim to get attention or opinions 
Putri Ariani : Relationship Between Academic Stress, Family And Peer Attachment

from their friends on social media. Also, social media can foster a positive image so that teenagers always give a good impression when on social media (Madden, Lenhart, Cortesi, Smith, \& Beaton, 2013).

Description of Academic Stress in Adolescents, table 2 showed adolescents who experienced academic stress were in the moderate category numbering $130(35.4 \%)$ adolescents. The results of this study found the academic stress was a source of the significant stressor for students. Stroud et al. (2009) stated that adolescents who easily experience stress are adolescents ranging in age from 1419 years, who at that age usually enter junior high school and senior high school. Huan et al. (2008) asserted that high school students are more susceptible to stress due to higher academic demands. As compensation, they use the internet excessively after school.

Description of Family Attachments in Adolescents, table 2 showed that family attachment was in the moderate category, namely $221(60.2 \%)$. The results of this study indicated that adolescents still had secure attachments with their parents. This is due to the family is the principal place for adolescents to form social and emotional conditions, especially the condition of adolescents who are entering the transition period for obtaining the basis in shaping their abilities so that later they become successful people in society. Armsden and Greenberg (2009) suggested parental attachment is a significant predictor of adolescent selfesteem.

The trust of adolescents in their parents is a critical component. Armsden and Greenberg, (2009) revealed that teenagers who trust in their parents would continue to need their parents when they are in a stressful and challenging situation. The study of Yusuf, Osman, $\mathrm{Hj}$, and Teimoury (2014) in Malaysia found that adolescents who have high trust in their parents will prevent them from getting involved in delinquency and help avoid teenagers from risky or distorted behaviors.

Description of Peer Attachment in Adolescents, table. 2 showed that peer attachments were in the moderate category, namely $201 \quad(34.9 \%)$. The study results showed peers had an essential role in the lives of adolescents. Attachment changes occur when teens learn and develop relationships with individuals other than families. Peer attachment is a bond that arises between adolescents and peers who are related to thoughts, feelings, and emotions (Baroccas, 2009).

The meta-analysis result by Gorrese and Ruggieri (2012) entitled Peer attachment: A meta-analytic review of gender and age and associations with parent attachments toward 54 studies, reported gender differences in the peer attachment. The results of the metaanalysis show that girls are significantly more attached to their peers than men.

The social support derived from peer groups can cause adolescents to have the opportunity to do various things they have never performed, and learn to take on new roles in their lives so that self-acceptance of peers' environment becomes something that is considered important (Tarakanita, 2008). Wilkinson's (2004) study found adolescence's attachment to peers is interwoven due to the personal experience of adolescents from interactions with their parents.

In adolescence, there is a shift in attachment, where friendship with peers is more than parents. Peers are considered more capable of understanding adolescent's problems, where adolescents can find more personal problems without feelings for peers than parents (Pitman \& Scharfe, 2010). The video seeks attachment in the form of advice, advice, and information as adolescents face various life problems. Adolescents like to ask for opinions from peers about things that concern them (Barrocas, 2009).

Relationship between Academic Stress and Internet Addiction in Adolescents, the results of the Spearman Rank test with a value of $\mathrm{p} 0.000(<0.05)$ and a correlation value $(r)$ of 0.525 indicated that there was a positive relationship between academic stress and internet addiction and the strength of moderate relationships which meant that the higher the academic stress, the higher the level of internet addiction in adolescents.

The General Strain Theory by Agnew 1992 (in Busari, 2016) is a framework that can be used to understand the relationship between academic stress, negative emotions, 
Putri Ariani : Relationship Between Academic Stress, Family And Peer Attachment

and internet addiction as well as various types of tension, including stress and negative social relationships that can lead to deviant behaviors. The study of Jun and Choi (2015) examined the association of academic stress mediated by negative emotions and their relationship with internet addiction to 512 adolescents in Korea. The results of this study indicate that adolescents who experience academic stress may be at risk of internet addiction especially when accompanied by negative emotions.

Prolonged academic stress can also result in losing interest, decreasing concentration and avoiding problems that can cause students to look for other activities to reduce academic stress such as accessing the internet (Jun \& Choi, 2015). Adolescents try to reduce academic pressure by switching to computers as a way to minimize academic burden and manage other uncomfortable feelings such as depression and anxiety related to study and school (Tiwari \& Shukla, 2014).

According to Wang, Zhou, and Lu (2011), the risk factors for adolescents experiencing internet addiction are related to stress, bad relationships with teachers and friends and experiencing conflict within the family. This opinion is in line with Bakken et al. (2009) who state that groups of adolescents aged 14 to 19 experienced internet addictions because they avoid stress and responsibility.

Relationship between Family Attachments and Internet Addiction in Adolescents, the results of the Spearman rank test to see parental attachment relationships and their relationship to internet addiction obtained a p-value of $0.000(<0.05)$ and a value $(r)$ of 0.398 , indicating there was a relationship between family attachments and internet addiction with a negative correlation and weak power relations. This means that the higher the family attachment, the lower the internet addiction in adolescents.

The results of this study are in line with the Developmental Model of Adolescent Problem Behavior by Ary et al. (1999) in Kuss et al. (2013) which state the lack of attachment to the family will cause a lack of monitoring to adolescents which will cause them to be involved in a problematic problem. Wright and Cullen (2007) state that when adolescents have a greater attachment to their parents and positive family interactions, adolescents feel obliged to act in the right way to please their parents and vice versa adolescents in families with low levels of conflict and family ties will refuse supervision and monitoring from parents.

According to Galambos, Barker, and Almeida (2003), the closeness and presence of physical parents can maintain a safe attachment in adolescents. This finding is in line with the study of Yen, Cen, and Ko (2007) in China who studied 3662 students, which found that there was a relationship between the lack of adherence of parents and adolescents and low family function to be one of the causes of adolescents experiencing internet addiction.

According to Davis (2005) when parents do not give sufficient attention and lack of parental support, adolescents tend to have an unstable psychological condition, and then add to the environment of fierce social competitions. Parents who focus on their children's academic achievements can cause adolescents to experience pressure. To compensate for this psychological stress, adolescents maintain their fulfillment, by building relationships and affection through cyberspace (Kim \& Haridakis, 2009). Adolescents who have negative feelings can contribute to the risk of internet addiction. In this case, parents play a role in giving direction, counseling, advising, explaining clear differences between right and wrong and providing protection in daily activities (Xiong, 2004; Yadav \& Nikalje, 2006).

An approach that focuses on parental involvement and communication through good quality communication is a promising way to prevent adolescents from becoming addicted to the Internet (Park, Kim, \& Cho, 2008; Van den Eijden, Spijkerman, Vermuls, Van Rooij \& Engels, 2009). This is in line with Floros and Siomos (2013) stating the need for the role of parents to care for and protect their children and respect their autonomy will reduce the motivation of adolescents to experience internet addiction.

Relationship of Peer Attachments to Internet Addiction in Adolescents, the results of Spearman Rank correlation analysis 
Putri Ariani : Relationship Between Academic Stress, Family And Peer Attachment

between peer attachments and internet addiction obtained a p-value of $0.000(<0.05)$ and a value (r) of 0.398 which showed there was a relationship between peer attachment and internet addiction in adolescents with a negative and weak link. It means that the higher the peer attachment, the lower the risk of internet addiction in adolescents.

The meta-analysis conducted by Gorrese and Ruggieri (2012) on 44 studies related to parent and peer attachment in adolescents, found that parental and peer attachments shared important meanings for adolescents. Teenagers need a safe and comfortable figure beside parents to listen to their various problems, give advice and support. The study also found that there were differences in attachments between boys and girls in general where girls were more attached to peers than boys. This is due to adolescent girls tend to have a higher level of trust and communication than adolescent boys.

In adolescence, individuals tend to seek closeness and comfort in the form of suggestion or advice to peers when they feel they need it (Barrocas, 2009). Communication and trust are also a product of a strong relationship, where both parties feel interdependent with each other (Armsden \& Greenberg, 2007). Santrock (2003) states that through peer interactions, adolescents learn about patterns of reciprocity. Adolescents explore the principles of honesty and justice by overcoming disagreements with peers; they also learn to observe the interests and views of peers to facilitate the process of integrating themselves into ongoing peer activities.

According to the Peer Cluster Theory by Oetting and Beauvais, 1987 (in Albert, Chein, \& Steinberg, 2013) peer is an active socialization agent and will actively shape other adolescents' behavior by changing their beliefs and attitudes that are in accordance with their peers. Peers who have negative behaviors will be a model for others to behave negatively (Bandura, 2001). Therefore adolescents can directly learn and adopt beliefs using the internet which will result in adolescents experiencing internet dependence (Urban, 2010).

Adolescents need friends to interact and socialize. Teenagers who have fewer friends will tend to overuse the internet to compensate for social interactions in the real world (Peter et al., 2005; Amichai \& Hamburger, 2003).

The Most Related Factor between Academic Stress, Family Attachments, and Peers with internet Addiction in Teens Adolescents. The result of multivariate analysis using logistic regression test obtained one variable that was most significantly related to internet addiction, namely family attachment with OR 0.297.

The study results are in line with the statement of Bowly (in Santrock 2002) which states that adolescents who experience a period of transition in life cause complex changes in the relationship of parents and children during adolescence. The increasing age of puberty will show a decrease in attachment to parents physically but remain stable for some matters. When teenagers experience stress and pressure, the need for close figures with parents is still vital. At the age of adolescence, having a more intimate relationship with peers is very important. However, parents will always provide the first sense of security in adolescents because the fixed figure has been established for a long time, Grendberg (in Santrock, 2005).

The relationship between adolescents and their parents helps create a strong emotional bond, one of which is seen from the quality of communication. Communication is an important indicator in the relationship of adolescents and parents which may cover various things including issues related to sex, religion to peers so that communication between parents and adolescents must always be maintained (Pearson \& Child, 2007). The poor communication of adolescents with parents causes adolescents more often to engage in risky behavior, one of which is excessive internet use (Essau, 2008).

The first growing trust builds the attachment between parents and children. Trust focuses on children's beliefs that parents are consistently there for them. Trust in adolescents to parents has the nature of the extent to which adolescents perceive that parents will always be there, feel dependent on parents, trust parents and get a sense of security from parents (Barrocas, 2008). For this reason, it is essential for parents to 
Putri Ariani : Relationship Between Academic Stress, Family And Peer Attachment

become figures who are always there when teenagers need them.

\section{Conclusion}

Study results show that there are relationships between academic stress, family attachments and peer attachments to internet addiction in adolescents. Of the three variables, the family attachment variable has a significant influence on internet addiction in adolescents. A proper family attachment can contribute to the psychological well-being of adolescents. A close relationship with parents can reduce the teenagers' free time being used excessively on the Internet and online social activities.

\section{References}

Akhtar, Z. (2011). The Effect of Parenting Styles of Parents on Attachment Styles of Undergraduate Students. Conference paper presented in International Conference of Education, Research and Innovation, Madrid: Spain.

Albert, D., Chein, J., \& Steinberg, L. (2013). Peer influences on adolescent decision making. Current Directions in Psychological Sciences Science, 22(2), 114-120. http://doi. org/10.1177/0963721412471347.

Amichai \& Hamburger. (2003). Loneliness and Internet use. Computers in Human Behavior, 19,71,71-80

APJII. (2016). Profil Pengguna Internet Indonesia 2012. Retrieved January, 14, 2017, available from: http:// www. apjii. or. id/ v2/ upload/ Laporan /Profil\% 20Internet \%20 Indonesia \%202012\%20(INDONESIA).pdf.

Armsden \& Greenberg. (2009). The inventory of parent and peer Attachment: Individual differences and their relationship to psychological well-being in adolescence. Journal of Youth and Adolescence, 16(5). doi: 0047-2891/87/1000-0427\$05.00/0.

Aydn, B., \& Sar, S.V. (2011). Internetaddiction among adolescents: The role of self-esteem.
Procedia-Social and Behavioral Sciences, 15, 3500-3505. https://doi.org/10.1016/j. sbspro.2011.04.325.

Bakken et al. (2009). Internet Addiction among Norwegian adult: a stratified probablility sample study. Scand J Psychol. DOI.10.1111/j.1467-9450.2008.00685.x.

Bandura. (2001). A sosiocognitive analysis of substance abuse : An agentic perspective. Psychological Science, 10, 214-217.

Baroccas. (2009). Adolescent Attachment to Parents and Peers. (Online). Retrieved April 8, 2017, from http://www.marial.emory.edu./ pdfs/barrocas $\% 20$ thesisfinal.doc.

Busari. (2016). Academic Stress and Internet Addiction among Adolescents: Solution Focused Social Interest Programme as Treatment Option. J Ment Disord Treat 2: 114. doi:10.4172/2471-271X.100011

Davis. (2005). A Cognitive-behavioral model of pathological internet use. Computers in Human Behavior, 17(2),187-195.

Dieres \& Hirche. (2017). Media use Internet in adult depression : A case-control study. Computers In Human Behavior 68 : 96-103

Essau et al. (2008). Doing it noworlater? Correlates, predictors and prevention of academic, decisionaland general procrastination among students in Austria. A Poster Presentation at the Presentation at the 8th Alps-Adria Psychology Conference, October 2-4, Ljubljana, Slovenia.

Floros \& Siomos (2013). Evolution of Internet addiction in Greek adolescent students over atwo-year period: the impact of parental bonding. European Child and Adolescent Psychiatry 21, 211-219.

Galambos, Barker, \& Almeida. (2003). Parents do matter: Trajectories of change in externalizing and internalizing problems in early adolescence. Child Development, 74, 578-594. doi:10.1111/1467-8624.7402017.

Gorrese \& Ruggieri. (2012). Peer Attachment: 
Putri Ariani : Relationship Between Academic Stress, Family And Peer Attachment

A Meta-Analytic Review of Gender and Age Differences and Associations with Parent Attachment. Journal of Youth and Adolescence, 41, 650-672. $\mathrm{http} / / / \mathrm{dx}$.doi.org/10.1007/s10964-012-97596.

Greenberg \& Armsden. (2009). The inventory of parent and peer Attachment: Individual differences and their relationship to psychological well-being in adolescence. Journal of Youth and Adolescence, 16(5). doi: 0047-2891/87/1000-0427\$05.00/0.

Gunuc, S. (2016). Peer influence in internet and digital game addicted adolescent: Is internet/digital game addiction contagious?. Int J High Risk Behav Addict, 10, 1-10. http:// doi.org/10.5812/ijhrba.33681.

Huan et al. (2008). The Impact of Adolescent concerns on their academic stress. Educational Review 60(2):169-178. May 2008. DOI. 10.1080/00131910801934045

Jun, S., \& Choi, E. (2015). Academic stress and internet addiction from general strain theory framework. Computer in Human Behavior, 49, 282-287. http://doi. org/10.1016/j.chb.2015.03.001.

Kandemir. (2014). Predictors of Academic Procrastination : Coping with Stress, Internet Addiction and Academic Motivation, 32(5), 930-938. https://doi.org/10.5829/idosi. wasj.2014.32.05.60.

Karimpoor, S., Ali, M., Chobegloo, M., Alizadeh, S., \& Talebi, B. (2013). Comparing internet addiction, feeling of loneliness, and educational progress in. Psychologically Healthy and At-Risk People, 19(1), 88-94.

Karuniawan \& Cahyanti. (2013). Hubungan antara Academic stres dengan Smartphone addiction pada mahasiswa pengguna Smartphone. Jurnal Psikologi Klinis dan Kesehatan Mental, 2(1), 16-21.

Kim \& Haridakis. (2009). The Role of Internet User Characteristics and Motives in Explaining Three Dimensions of Internet
Addiction. Journal of Compter Mediated Communication 14 (4):988-1015.

Kuss, D.J., Van Rooij, A.J., Shorter, G.W., Griffiths, M.D., \& Van de Mheen, D. (2013). Internet addiction in adolescents: Prevalence and risk factors. Computers in Human Behavior, 29(5), 1987-1996. http://doi. org/10.1016/j.chb.2013.04.002.

Lenhart, A., Rainie, L., \& Lewis, O. (2001). Teenage life online: The rise of theinstantmessage generation and the internets' impact on friendships and family relationships. Pew Internet and American Life Project.

Madden, A. Lenhart, S. Cortesi, U. Gasser, M. Duggan, A. Smith and M. Beaton. (2013). Teens, Social Media, and Privacy," Pew Internet \& American Life Project. http:// www.pewinternet.org/Reports/2013/TeensSocial-Media-And-Privacy.aspx.

Öztürk, C., Bektas, M., Ayar, D., Özgüven Öztornaci, B., \& Yatci, D. (2015). Association of personality traits and risk of internet addiction in adolescents. Asian Nursing Research, 9(2), 120-124. https://doi. org/10.1016/j.anr.2015.01.001.

Park, S.M., Park, Y.A., Lee, H.W., Jung, H.Y., Lee, J.Y., \& Choi, J.S. (2013). The effects of behavioral inhibition/approach system as predictors of internet addiction in adolescents. Personality and Individual Differences, 54(1), 7-11. https://doi. org/10.1016/j.paid.2012.07.033.

Pattayakorn. (2012). Internet Addiction, Stress, And Academic Outcome Among Undergraduate Students of An International in Thailand, American Canadian Conference.

Pearson, J.C. \& Child, J.T. (2007). A crosscultural comparison of parental and peer attachment styles among adult children from the United States, Puerto Rico, and India. Journal of Intercultural Communication Research. 36(1): 15-32.

Permatasari (2016). Pengaruh Stres dengan Kecendrungan Kecanduan Internet 
Putri Ariani : Relationship Between Academic Stress, Family And Peer Attachment

\section{Pada Remaja. Tesis.}

Peter et al. (2005). Developing a Model of Adolescent Friendship Formation On the Internet. CyberPsychology \& Behavior 8 (5):423-430. DOI:10.1089/cpb.2005.8423.

Pitman \& Scharfe. (2010). Testing the function of attachment hierarchies during emerging adulthood. Personal Relationships, 17, 201-216.

Piyike, Bidjuni, \& Wowiling. (2014). Hubungan tingkat stres dengan durasi bermain Game Online pada remaja di Manado. Jurnal keperawatan, 2(2), 1-7.

Saleem, Khan, \& Ismail. (2015). Internet Addiction: Its's Relation With Loneliness Among Undergraduate Students Of SouthPunjab, Pakistan. Sci.Int(Labore), 27(2), 1479-1479.2015.

Santrock, J.W. (2005). Psychology update ( $7^{\text {th }}$ Ed.). New York: The McGraw Hill. Companies. Inc .

Soh, Charlton, \& Chew. (2014). The influence of Parental and Peer Attachment on Internet Usage Motives and addiction. Fisrt Monday 19 (7). DOI:10.5210/fm.v19i7.5099.

Stanhope, M., \& Lancaster, J. (2004). Community \& public health nursing $\left(6^{\text {th }} \mathrm{Ed}\right.$. $)$. Missouri: Mosby Elsivier Inc.

Stroud et al. (2009). Stres Respon and The Adolescent Transition : Performance versus Peer Rejection Stressors. Dev Psychopathol. 21(1): 47-68. doi:10.1017/ S0954579409000042.

Tarakanita. (2008). Hubungan status identitas etnik dengan konsep diri mahasiswa. Jurnal Psikologi, 7(1). 01-14.

Tiwari \& Shukla. (2014). Perceived interparental relationship and anxiety among adolescents: mediating role of perceived parental support. Indian Journal of Community Psychology, 11(2), 244-258 ISSN-0974-2719.
Tsitsika, A., Critselis, E., Louizou, A., Janikian, M., Freskou, A., Marangou, E., ... Kafetzis, D. (2011). Determinants of internet addiction among adolescents: A case-control study. The Scientific World Journal, 11, 866874. http://doi.org/10.1100/tsw.2011.85.

Urban., R, Farkas., J,Kiraly, Kokoyei, Elekes.,Z Tamas, D., Demotrovics Z (2014). Problematic Internet Use and Problematic Online Gaming Are Not the Same: Findings from a Large Nationally Representative Adolescent Sample. Cyberpsychology, Behavior, and Social Networking, 17(12). |https://doi.org/10.1089/cyber.2014.0475.

Van den Eijden, Spijkerman, Vermuls, Van Rooij, \& Engels. (2009).

Wang, H., Zhou, X., Lu, C., Wu, J., Deng, X., \& Hong, L. (2011). Problematic internet use in high school students in Guangdong Province. China, 6(5). https://doi.org/10.1371/journal. pone. 0019660 .

Wilkinson's. (2004). The role of parental and peer attachment in the psychological health and self-esteem of adolescents. Journal of Youth and Adolescence, 33(6), 479-492.

World Health Organization. (2015) World health statistik. Retrieved February, 3, 2017, available from: www.who.int.

Wright \& Cullen. (2007). Parental efficacy and delinquent behavior: Do control and support matter? Criminology, 39, 677-705. doi:10.1111/j.1745-9125.2001.tb00937.

Wu et al. (2016). Wu, C.-Y., Lee, M.-B., Liao, S.-C., \& Chang, L.-R. (2015). Risk Factors of Internet Addiction among Internet Users: An Online Questionnaire Survey. PloS One, 10(10), 1-10. http://doi.org/10.1371/journal. pone.0137506.

Xiong. (2004). Southeast Asian adolescent perception of immigrant parenting practices. Hmong Stud J, 5:1 - 20.

Yadav \& Nikalje. (2006). Comparison of high and low efficient schools in terms of school, 
Putri Arian : Relationship Between Academic Stress, Family And Peer Attachment

pupil and home-related variables. $J$ Indian Educ, 32:5-21.

Yang \& Tung. (2014). Comparison of Internet addicts and non-addicts in Taiwanese high school. Computers in Human Behavior 23: 79-96

Yen, J.Y., Yen, C.F., Chen, C.C., Chen, S.H.,
\& Ko, C.H. (2007). Family factors of internet addiction and substance use experience in Taiwanese adolescents. Cyberpsychol. Behav. $10,323-329$.

Yusuf, S., Osman, N., Hj, S., \& Teimoury, M. (2014). Parents' influence on children's online usage. Procedia - Social and Behavioral Sciences, 155, 81-86. 